\title{
PENGARUH KUALITAS PELAYANAN TERHADAP KEPUASAN NASABAH PADA PT. BPRS BERKAH DANA FADHILILAH AIR TIRIS KAMPAR
}

\author{
${ }^{1}$ Aai Mustika. ${ }^{2}$ Rita Riska \\ Sekolah Tinggi Ilmu Ekonomi Riau \\ E-mail: aai.mustikamm1228@gmail.com
}

\begin{abstract}
The Effect of service quality on customer satisfaction at PT. BPRS Berkah Dana Fadhililah Air Tiris Kampar. The purpose of this study was to determine the effect of service quality on customer satisfaction at PT. BPRS Berkah Dana Fadhililah Air Tiris Kampar. The sample in this study were 99 people taken randomly. The survey results in the field obtained the level of customer service quality seen from the five dimensions of assessment (Tangible - Physical appearance, Responsiveness - Speed, Assurance - guarantee, Reliability - Performance, Empathy care) at PT. BPRS Berkah Dana Fadhililah Air Tiris Kampar, from the results of the analysis of the five dimensions, the Empathy dimension (Service to customers does not distinguish social status) is the most dominant according to the responses of respondents with an average of 4.64. Regression equation obtained by $Y=24.298+0.541 X$, testing the hypothesis with t_count 6.518 (greater than $t$ table ie 1.984) and P-Value $<0.05(0.00<0.05)$ then Ho is rejected, while the coefficient of determination is $30.5 \%$, meaning $30.5 \%$ satisfaction customers affected by the remaining service quality $69.5 \%$ are influenced by other factors.
\end{abstract}

Keywords: Kualitas pelayanan dan Kepuasan nasabah

\section{A. PENDAHULUAN}

Dalam era perdagangan bebas, setiap perusahaan menghadapi persaingan yang ketat. Meningkatnya intensitas persaingan dan jumlah pesaing menuntut perusahaan untuk selalu memperhatikan kebutuhan dan keinginan konsumen serta berusaha memenuhi harapan konsumen dengan cara memberikan pelayanan yang lebih memuaskan dari yang dilakukan oleh pesaing. Salah satu jenis perusahaan yang bergerak disektor jasa adalah Bank.

Bank adalah sebuah lembaga intermediasi keuangan umumnya didirikan dengan kewenangan untuk menerima simpanan uang, meminjamkan uang, dan menerbitkan promes atau yang dikenal sebagai banknote. Bank merupakan badan usaha yang menghimpun dana dari masyarakat dalam bentuk simpanan dana dan menyalurkan kepada masyarakat dalam bentuk kredit atau bentuk-bentuk lainnya dalam rangka meningkatkan taraf hidup masyarakat banyak.

Untuk memperoleh kepercayaan dari masyarakat, maka sektor perbankan harus dikelola secara profesional mulai dari segi pelayanannya, strategi pemasaran yang baik. Tujuan memberika pelayanan yang baik kepada nasabah yaitu agar nasabah merasa puas dan setia kepada produk yang perusahaan tawarkan. Kualitas yang baik juga dapat dijadikan sebagai sarana promosi,

Di Indonesia ada bank konvesional dan bank syariah, yang mana belakangan ini banyak bank konvensional membuka bank syariah juga seperti bank Mandiri, BRI, Dengan kemunculan bank syariah ini menambah ketat persaingan bank untuk menarik simpati calon nasabah.

Salah satunya PT. BPRS Berkah Dana Fadhlillah Air Tiris, sebagai lembaga keuangan syariah semua jasa dan produk yang disalurkan berdasarkan prinsip 
syariah. Sebagaimana yang telah ditetapkan oleh bank syariah-syariah sebelumnya yaitu Bank Muamalat Indonesia. PT. BPRS Berkah Dana Fadhlillah Kampar yaitu bank yang memberikan pendanaan kepada rakyat secara syariah tentunya dengan kualitas pelayanan yang baik agar nasabah mendapatkan kepuasan dan bisa terus menerus menjalin kerja sama dengan PT. BPRS Berkah Dana Fadhlillah Kampar. Kualitas pelayanan yang baik kepada nasabah akan meningkatkan kepercayaan terhadap bank dan pemberian pelayanan yang baik juga akan menimbulkan cita rasa yang baik pada nasabah. Kepuasan bisa juga diartiakan apa yang diharakan nasabah menjadi kenyataan yang mereka terima.

Ketika nasabah mendapatkan kepuasan mereka akan menyebarkan word of mouth secara positif, secara tidak lansung nasabah telah mempromosikan bank kepada masyarakat sehingga masyarakat mengenal dan tertarik untuk bergabung menjadi nasabah di bank tersebut. Begitu pula sebaliknya jika nasabah mendapat pelayanan kurang baik mereka akan menyebarkan word of mouth secara negatif dan dampak yang diterima bank pastinya juga negatif. Maka dari itu kualitas pelayanan sangatlah penting di dalam perusahaan terutama yang bergerak di bidang jasa.

Ada beberapa fenomenal yang penulis temukan saat observasi dilapangan dan ini berhubungan dengan kualitas pelayanan yang diberikan PT. BPRS Berkah Dana Fadhililah Kampar berbeda dengan bank pada umum lainya yang mana nasabah ketika membuka pintu saja sudah disambut dengan senyuman dan sapaan satpam tetapi pada PT. BPRS Berkah Dana Fadhiliah, ketika nasabah datang, mereka lansung menuju kasir atau teller untuk melakukan transaksi. Tidak adanya pengambilan nomor antrian, hal ini tidak menimbulkan masalah jika nasabah yang datang dalam jumlah sedikit tetapi jika nasabah yang datang sekaligus banyak, mereka akan rebutan menuju teller karena tidak tersedianya antrian khusus dari pihak PT. BPRS Berkah Dana Fadhililah Kampar bagi nasabah yang cerdik

Eko dan Bisnis (Riau Economics and Business Reviewe) Volume 10, Nomor 4, 27 Desember 2019 mereka akan mencari cara untuk bisa duluan ke kasir padahal ada nasabah yang duluan datang, ini akan menimbulkan kekesalan dan menganggu kenyamanan nasabah lain. Ditambah lagi teller atau kasir yang melayani cuma satu orang dan satu orang bagian informasi sehingga ini tidak menutup kemungkinan tellernya akan kewalahan.

Akibatnya nasabah akan menunggu terlalu lama untuk bisa mendapatkan pelayanan. Untuk mengetahui tingkat kepuasan nasabah kita bisa melihat data pertumbuhan jumlah nasabah. Untuk lebih jelasnya bisa kita perthatikan tabel 1 dimana disana akan terlihat jumlah nasabah PT. BPRS Berkah Dana Fadhlillah Kampar.

Tabel Data Jumlah Nasabah PT. BPRS Berkah Dana Fadhillah Kampar

\begin{tabular}{|l|r|r|r|r|r|}
\hline \multirow{2}{*}{ Jenis } & \multicolumn{5}{|c|}{ Jumlah Nasabah } \\
\cline { 2 - 6 } & 2013 & 2014 & \multicolumn{1}{|c|}{2015} & \multicolumn{1}{c|}{2016} & \multicolumn{1}{c|}{2017} \\
\hline Tabungan & 7.958 & 7.870 & 8.361 & 8.709 & 9.144 \\
\hline Deposito & 55 & 48 & 53 & 68 & 91 \\
\hline Pembiayaan & 855 & 516 & 406 & 445 & 521 \\
\hline Total & 8.868 & 8.434 & 8.820 & 9.222 & 9.756 \\
\hline
\end{tabular}

Sumber : PT.BPRS Berkah Dana Fadhlillah Kampar, 2018

Pada tabel 1 bisa dilihat pertumbuhan jumlah nasabah PT. BPRS Berkah Dana Fadhlilah Kampar mengalami flukluatif dimana di tahun 2013 terdapat 8.868 nasabah, tahun 2014 terjadi penurunan menjadi 8.434 nasabah, tahun 2015 nasabah meningkat mejadi 8.820 nasabah, pada tahun 2016 jumlah nasabah meningkat menjadi 9.222. Pada tahun 2017 mencapai 9.756 nasabah. Dari lima tahun terakhir pada tahun 2014 yang terjadi penurunan jumlah nasabah baik nasabah tabungan, deposito dan pembiayaan semuanya mengalami penurunan.

Jumlah penurunan nasabah ini mengalami dampak terhadap pencapaian dari target yang telah ditentukan oleh PT. BPRS Berkah Dana Fadhlilah Kampar yang dapat dilihat pada tabel berikut: 
Tabel Data Jumlah Target dan Pencapaian PT. BPRS Berkah Dana Fadhillah Kampar

\begin{tabular}{|c|c|c|c|}
\hline Tahun & Target (Rp) & Pencapaian (Rp) & Persentase \\
\hline 2013 & 15.533 .010 .000 & 15.131 .966 .255 & $97.42 \%$ \\
\hline 2014 & 17.543 .611 .070 & 16.000 .497 .317 & $91.20 \%$ \\
\hline 2015 & 17.937 .967 .645 & 16.593 .721 .270 & $92.51 \%$ \\
\hline 2016 & 20.093 .033 .755 & 22.165 .093 .618 & $110.31 \%$ \\
\hline 2017 & 21.199 .020 .257 & 26.642 .177 .478 & $125.68 \%$ \\
\hline
\end{tabular}

Dari tabel di atas dapat dilihat bahwa Pada tahun 2013 target pemasukan dari tabungan dan deposito Rp. 15.533.010.000 dengan pencapaian Rp. 15.131.966.255 atau $97.42 \%$.Pada tahun 2014 pencapaian yang diperoleh turun $6.22 \%$ yakni menjadi $91.20 \%$ . pada tahun 2015 PT. BPRS Berkah Dana Fadhililah Kampar menargetkan Rp. 17.937.967.645 dri target tersebut yang tercapai hanya Rp. 16.593.721.270 atau 92.51\% dan tahun 2016 dan 2017 PT. BPRS Berkah Dana Fadhililah Kampar bisa melewati target dengan pencapaian $110.31 \%$ dan $125.68 \%$ pada tahun 2017 , ini adalah pencapaian yang paling tinggi dalam waktu lima tahun terakhir.

Pencapain yang diperoleh oleh PT. BPRS Berkah Dana Fadhilah Kampar tidak lepas dari berbagai perencanaan, kerja keras, kedisipilinan dan berbagai upaya untuk mengatasi permasalahan yang ada, sehingga kinerja karyawan menjadi baik. Salah satu masalah yang ada disana yang dijadikan bahan untuk perbaikan adalah adanya berbagai keluhan yang dirasakan oleh nasabah, diantara keluhan tersebut diantaranya dapat dilihat pada tabel berikut:

Tabel Data Jumlah Keluhan Nasabah di PT. BPRS Berkah Dana Fadhillah Kampar

\begin{tabular}{|l|c|}
\hline \multicolumn{1}{|c|}{ Keluhan } & Keterangan \\
\hline $\begin{array}{l}\text { Kurangnya pengetahuan/pemahaman } \\
\text { karyawan dalam bekerja }\end{array}$ & 1 Orang \\
\hline $\begin{array}{l}\text { Kurang ramah ketika melayani } \\
\text { nasabah }\end{array}$ & 5 Orang \\
\hline
\end{tabular}

Dari data keluhan di Tabel 1.3 di atas dapat dipahami bahwa nasabah mengeluhkan karyawan yang kurang memiliki pengetahuan dan pemahaman terhadap pekerjan yang mereka lakukan . nasabah juga mengeluhkan kurang ramahnya pelayanan yang diberikan oleh karyawan. Dalam hal ini perusahaan terus melakukan perbaikan agar nasabah puas dengan pelayanan yang diberikan oleh perusahaan.

Pelayanan yang diberikan oleh PT. BPRS Berkah Dana Fadhillah Kampar tidak hanya diberikan antara karyawan dan nasabah tetapi juga melalui sarana atau fasilitas yang diberikan kepada nasabah selama berada di PT. BPRS Berkah Dana Fadhillah Kampar. Berikut fasilitas yang diberikan oleh perusahaan kepada nasabah:

Tabel Data Fasilitas Sarana dan Prasarana di PT. BPRS Berkah Dana Fadhillah Kampar

\begin{tabular}{|r|c|}
\hline$N_{0}$ & Jenis Fasilitas \\
\hline 1 & 1 Kipas di Ruang Tunggu \\
\hline 2 & Area Parkir \\
\hline 3 & 2 Kursi Panjang di Ruang Tunggu \\
\hline 4 & Toilet \\
\hline
\end{tabular}

Dari tabel 1.4 di atas dapat dipahami bahwa perusahaan berusaha memberikan pelayanan yang terbaik kepada nasabah. Hal ini diharapkan akan mampu membuat nasabah merasa nyaman selama melakukan transaksi.

\section{Pengertian Pemasaran}

Pemasaran menurut Kotler dan Keller (2009:5) diterjemahkan Bob Sabran, American Marketing Association mendefinisikan Pemasaran adalah suatu fungsi organisasi dan serangkaian proses untuk menciptakan, mengomunikasikan, dan memberikan nilai kepada pelangan dan untuk mengelola hubungan pelangan dengan cara yang menguntungkan organisasi dan pemangku kepentingan,

Menurut Stanton dalam Chairiza (2012:15) pemasaran adalah : “ Suatu system keseluruhan dari kegiatan-kegiatan usaha yang ditujukan untuk merencanakan, menentukan harga, mempromosikan, mendistribusikan barang dan jasa yang memuaskan kebutuhan baik kepada 
konsumen atau pembeli yang ada maupun pembeli potensial."

Menurut Rahmat, (2018;329) mengatakan manajemen pemasaran adalah proses yang dilakukan perusahaan atau individu untuk berinteraksi dengan pelanggan guna memberikan nilai perusahaan agar membangun hubungan timbal balik antara perusahaan dengan pelanggan.

\section{Pengertian Kualitas Pelayanan}

Kualitas merupakan salah satu kunci dalam memenangkan persaingan dengan pasar. Ketika perusahaan telah mampu menyediakan produk berkualitas maka telah membangun salah satu fondasi untuk menciptakan kepuasan pelanggan.

Menurut Sunyoto (2012:236), "Mutu pelayanan berpusat pada upaya pemenuhan kebutuhan dan keinginan konsumen serta ketepatan penyampaiannya untuk mengimbangi harapan konsumen, yaitu adanya kesesuaian antara harapan dengan persepsi manajemen, adanya kesesuaian antara persepsi atas harapan konsumen dengan standar kerja karyawan, adanya kesesuaian antara standar kerja karyawan dengan pelayanan yang diberikan dengan pelayanan yang dijanjikan dan adanya kesesuaian antara pelayanan yang diterima dengan yang diharapkan dengan konsumen".

Berdasarkan definisi diatas penulis menyimpulkan bahwa kualitas pelayanan merupakan suatu penyajian produk atau jasa yang sesuai dengan standar perusahaan dan diupayakan dalam penyampaian produk dan jasa tersebut sama dengan apa yang diharapkan konsumen atau melebihi ekspetasi.

Menurut Garvin (1984) yang dikutip oleh Tjiptono (2012:143), setidaknya ada lima perspektif kualitas yang berkembang saat ini:

\section{Transcendental Approach}

Dalam persoektif ini, kualitas dipandang sebagai innate excellence, yaitu sesuatu yang secara intuitif dapat dipahami, namun nyaris tidak mungkin dikomunikasikan, sebagai conoh kecantikan atau cinta.
Perpektif ini menegaskan bahwa orang hanya bisa belajar memahami kualitas melalui pengalaman yang didapatkan dan eksposure berulang kali (repeated exposure)

\section{Product-Based Approach}

Perspektif ini mengasumsikan bahwa kualitas merupakan karakteristik, komponen atau atribut objektif yang dapat dikuantitatifkan dan dapat diukur. Perbedaan dalam hal kualitas mencerminkan perbedaan dalam jumlah beberapa unsur atau atribut yang dimiliki produk. Semakin banyak atribut yang dimiliki sebuah produk atau merek, semakin berkualitas produk atau merek bersangkutan.

\section{User-Based Approach}

Perspektif ini didasarkan pada pemikiran bahwa kualitas tergantung pada orang yang menilainya (eyes of the beholder), sehingga produk yang paling memuaskan preferensi seseorang (maximum satisfaction) merupakan produk yang berkualitas paling tinggi. Perspektif yang bersifat subyektif dan demandoriented ini juga menyatakan bahwa setiap pelanggan memiliki kebutuhan dan keinginan masing-masing yang berbeda satu sama lain, sehingga kualitas bagi seseorang adalah sama dengan kepuasan maksimum yang dirasakan.

4. Manufacturing-Based Approach

Perspektif ini bersifat supply-based dan lebih berfokus pada praktik-praktik perekayasaan dan pemanufakturan, serta mendefinisikan kualitas sebagai kesesuaian atau kecocokan dengan persyaratan (conformance to requirements). Dalam konteks bisnis jasa, kualitas berdasarkan perspektif ini cenderung bersifat operation-driven .

5. Value-Based Approach

Perspektif ini memandang kualitas dari aspek nilai (value) dan harga (price). Dengan mempertimbangkan trade-off antara kinerja dan harga, kualitas didefinisikan sebagai affordable excellence, yakni tingkat kinerja 'terbaik' atau sepadan dengan harga yang dibayarkan. Kualitas dalam perspektif ini bersifat relatif, sehingga produk yang memiliki kualitas paling bernilai adalah 
barang atau jasa yang paling tepat dibeli (best-buy).

Apabila jasa yang diterima atau dirasakan sesuai dengan yang diharapkan, maka kualitas jasa dipersepsikan baik dan memuaskan. Jika jasa yang diterima atau dirasakan melampaui harapan pelanggan, maka kualitas jasa dipersepsikan sebagai kualitas yang ideal. Sebaliknya jiak jasa dipersepsikan sebagai kualitas yang buruk. Kualitas harus dimulai dari kebutuhan pelanggan dan berakhir pada persepsi konsumen. Konsumenlah yang menentukan berkualitas atau tidaknya suatu pelayanan jasa. Dengan demikian baik tidaknya kualitas jasa tergantung pada kemampuan penyedia jasa dalam memenuhi harapan konsumen secara konsisten.

\section{Indikator Kualitas Pelayanan}

Menurut Zeithaml, Berry dan Parasuraman yang dikutip oleh Lovelock, Wirtz dan Mussry (2011:154) diterjemahkan oleh Dian Wulandari dan Devri Barnadi Putera terdapat lima dimensi pokok dalam kualitas pelayanan sebagai berikut:

1. Reliability (Kinerja yang dapat diandalkan dan akurat)

Berkaitan dengan kemampuan perusahaan untuk memberikan pelayanan yang akurat sejak pertama kali tanpa melakukan kesalahan apapun dan menyampaikan jasanya sesuai dengan waktu yang disepakati.

2. Responsiveness (Kecepatan dan kegunaan)

Berhubungan dengan kesediaan dan kemampuan karyawan untuk membantu para konsumen dan merespon permintaan mereka, serta menginformasikan kapan jasa akan diberikan dan kemudian memberikan jasa secara cepat.

3. Assurance (Kredibilitas, keamanan, kompetensi dan kesopanan)

Perilaku karyawan yang mampu menumbuhkan kepercayaan konsumen terhadap perusahaan dan perusahaan bisa menciptakan rasa aman bagi para konsumennya.
Jaminan juga berarti bahwa para karyawan selalu bersikap sopan dan menguasai pengetahuan dan keterampilan yang dibutuhkan untuk menangani setiap pertanyaan atau masalah konsumen.

4. Empathy (Akses mudah, komunikasi yang baik dan pemahaman pelangan)

Menyatakan bahwa perusahaan memahami masalah para konsumennya dan bertindak demi kepentingan konsumen, serta memberikan perhatian personal kepada para konsumen dan memiliki jam operasi yang nyaman.

5. Tangible (Penampilan unsur fisik)

Berkenaan dengan daya tarik fasilitas fisik, peralatan atau perlengkapan yang lengkap dan material yang digunakan perusahaan bersih serta penampilan dari karyawan rapi.

Berdasarkan kelima dimensi kualitas layanan tersebut, maka kepuasan pelanggan dapat diukur, dipahami dan dijadikan sebagai suatu hasil yang baik untuk kepentingan peningkatan kualitas pelayanan jasa yang diberikan kepada pelanggan, baik pelanggan yang baru pertama kali maupun pelanggan yang sudah berulang-ulang menggunakan jasa tersebut.

\section{Pengertian Kepuasan}

Menurut Kotler \& Keller (2009:138) diterjemahkan oleh Bob Sabran kepuasan (satisfaction) adalah perasaan senang atau kecewa seseorang yang timbul karena membandingkan kinerja yang dipersepsikan produk (atau hasil) terhadap ekspetasi mereka. Jika kinerja sesuai dengan ekspetasi, pelangan akan puas.

Menurut Tjiptono (2014:353) , kepuasan berasal dari bahasa Latin "Satis" yang berarti cukup baik, memadai dan "Facio" yang berarti melakukan atau membuat. Secara sederhana kepuasan bisa diartikan sebagai upaya pemenuhan sesuatu atau membuat sesuatu memadai. 
Berdasarkan kerangka definisional yang disusun oleh Giese dan Cote (2000) yang dikutip oleh Tjiptono dan Chandra (2011:292), kepuasan pelanggan adalah:

1. Rangkuman berbagai intensitas respon aktif. Tipe respon efektif dan tingkat intensitas yang mungkin dialami konsumen harus didefinisikan secara eksplisit oleh peneliti, tergantung pada konteks penelitiannya.

2. Dalam waktu penentuan spesifik dan durasi terbatas. Peneliti harus menentukan waktu penentuan yang paling relevan dengan masalah penelitiannya dan mengidentifikasi kemungkinan durasi respon tersebut.

3. Yang ditujukan bagi aspek penting dalam pemerolehan dan atau konsumsi produk. Peneliti harus mengidentifikasi focus riset berdasarkan pertanyaan riset atau masalah manajerial yang dihadapi. Fokus ini bisa luas maupun sempit cakupannya dalam hal isu atau aktivitas pemerolehan atau konsumsi produk.

\section{Indikator Kepuasan}

Dimensi Kepuasan Pelanggan, hal yang dapat mempengaruhi kepuasan pelanggan dapat dilihat dari ukuran atau dimensi kepuasan pelanggan menurut Kotler \& Keller (2009:140) diterjemahkan oleh Bob Sabran, yaitu:

a. Tetap setia untuk waktu yang lebih lama. Konsumen yang terpuaskan cenderung akan menjadi setia atau loyal. Konsumen yang puas terhadap produk yang dikonsumsinya akan mempunyai kecenderungan untuk membeli ulang dari produsen yang sama.

b. Membeli produk baru yang ditawarkan dan memperbaharui produk lama. Keinginan untuk membeli produk baru yang ditawarkan karena adanya keinginan untuk memperbaharui atau mecoba produk baru yang dikeluarkan perusahaan.

c. Membicarakan hal-hal baik tentang perusahaan dan merekomendasikan produknya kepada orang lain. Kepuasan merupakan faktor yang mendorong adanya komunikasi dari mulut kemulut (word of mouth communication) yang bersifat positif. Hal ini dapat berupa rekomendasi kepada calon konsumen yang lain dan mengatakan hal-hal yang baik mengenai produk dan perusahaan yang menyediakan produk.

d. Tidak terlalu memperhatikan merk pesaing dan harga. Jika konsumen telah mendapatkan kepuasan biasanya mereka akan fokus dengan merk yang sama dan tidak terlalu memperhatikan merk peasaing. Harga selalu dikaitkan dengan kualitas dari suatu produk/jasa dan ketika konsumen mendapatkan kepuasan harga mahal tidak terlalu dipermasalahkan.

e. Memberi masukan atau ide. Walaupun kepuasan sudah tercapai, konsumen selalu menginginkan yang lebih lagi, maka konsumen akan memberi masukan atau saran agar keinginan mereka dapat tercapai.

f. Biaya pelayan lebih murah. Mendapatkan biaya pelayanan yang lebih murah dibandingkan pelangan baru karena sering melakukan transaksi.

Untuk dapat memuaskan kebutuhan pelanggan, perusahaan dapat melakukan beberapa tahapan Zulian Yamit (2013:94) :

a. Mengetahui kebutuhan dan keinginan pelanggan

b. Mengetahui proses pengambilan keputusan dalam membeli produk

c. Membangun citra perusahaan

d. Membangun kesadaran akan pentingnya kepuasan pelanggan 
Pengaruh Kualitas Pelayanan terhadap Kepuasan

Menurut Zeithaml dan Bitner (2010:105) diterjemahkan oleh Ratih Hurriyati, salah satu yang mempengaruhi kepuasan pelanggan adalah ATTRIBUTION FOR SERVICE SUCCESS OR FAILURE (KEGAGALAN ATAU KEBERHASILAN PELAYANAN). Pelayanan yang diberikan kepada pelanggan dapat menjadi lebih buruk atau lebih baik dari yang diharapkan. Apabila pelayanan yang diberikan sesuai atau bahkan melampaui harapan pelanggan, maka dapat dikatakan pelayanan tersebut adalah pelayanan yang sukses, sebaliknya apabila pelayanan yang diberikan tidak sesuai dengan harapan pelanggan, maka dapat dikatakan bahwa proses pelayanan tersebut mengalami kegagalan. Dalam kesuksesan dan kegagalan penyampaian proses pelayanan tersebut, pelanggan akan mencari tahu penyebab dari kesuksesan atau kegagalan penyampaian pelayanan. Kegiatan pelanggan dalam mencari tahu penyebab suatu kesuksesan dan/atau kegagalan inilah yang dapat mempengaruhi tingkat kepuasan pelanggan terhadap suatu barang dan jasa.

\section{METODE}

\section{Uji Validitas}

Uji validitas digunakan untuk mengukur sah atau tidaknya suatu kuesioner. Suatu kuesioner dikatakan valid jika pertanyaan pada kuesioner mampu mengungkapkan sesuatu yang diukur oleh kuesioner tersebut. Untuk mengetahui konsistensi dan akurasi data yang di kumpulkan dari penggunaan instrumen kuesioner di lakukan uji validitas dengan menggunakan korelasi Spearman Rank. Sebuah item di katakan valid bila $r$ hitung $>r$ table (Sugiyono, 2010:267). Untuk menguji validitas instrumen dalam penelitian ini menggunakan SPSS 23.

\section{Uji Reliabilitas}

Setelah seluruh item kuesioner di nyatakan valid, maka selanjutnya dilakukan uji reliabilitas yang bertujuan untuk menguji sejauh mana pengukuran tetap konsisten, apabila di lakukan pengukuran dua kali atau lebih terhadap gejala yang sama dengan alat ukur yang sama nantinya. Uji realibilitas di lakukan dengan uji statistik Crobach'a Alpha. Suatu kontruk atau variabel dikatakan reliabel jika nilai Crobach'a Alpha > 0,6 (Sugiyono, 2010:354)

\section{Uji Normalitas}

Menurut (Ghozali, 2013:110) tujuan dari uji normalitas adalah untuk mengetahui apakah masing-masing variabel bertrisbusi normal atau tidak. Uji normalitas diperlukan karena untuk melakukan pengujian-pengujian variabel lainya dengan mengasumsikan bahwa nilai residual mengikuti distribusi normal. Adapun pengambilan keputusan didasarkan kepada:

1. Jika data menyebar di sekitar garis diagonal dan mengikuti arah garis diagonal, atau grafik histogramnya menunjukkan pola distribusi normal, maka model regresi memenuhi asumsi normalitas.

2. Jika data menyebar jauh dari garis diagonal dan atau tidak mengikuti arah garis diagonal, atau grafik histogram tidak menunjukkan pola distribusi normal, maka model regresi tidak memenuhi asumsi normalitas.

\section{Uji Regresi Linier Sedehana}

Dalam menganalisis data hasil penelitian ini, maka pada tahap pertama peneliti melakukan pengujian kuesioner, yaitu uji validitas dan reabilitas. Untuk melihat pengaruh pelaksanaan strategi diferensiasi terhadap keunggulan bersaing digunakan model regresi linier sederhana yaitu sebagai berikut:

Persamaan regresinya : $\mathrm{Y}=\mathrm{a}+\mathrm{bX}$

Dimana :

$\mathrm{Y}=$ Kepuasan Nasabah

$\mathrm{X}=$ Kualitas Pelayanan

$\mathrm{a}=$ Parameter konstanta

$\mathrm{b}=$ Parameter koefisien regresi 


\section{Uji Hipotesis}

\section{a. Uji_t}

Menurut Ghozali ( 2013:98 ), uji statistik $t$ pada dasarnya menunjukkan seberapa jauh pengaruh satu variabel penjelas atau independen secara individual dalam menerangkan variasi variabel dependen. Salah satu cara melakukan uji $t$ adalah dengan membandingkan nilai statistik $t$ dengan baik kritis menurut tabel. Sedangkan menurut Sugiyono (2011:194) uji t digunakan untuk mengetahui masing-masing sumbangan variabel bebas secara parsial terhadap variabel terikat, menggunakan uji masing-masing koefisien regresi variabel bebas apakah mempunyai pengaruh yang bermakna atau tidak terhadap variabel terikat Untuk menguji apakah masing-masing variabel bebas berpengaruh secara signifikan terhadap variabel terikat secara parsial dengan $\alpha=0,05$. Maka cara yang dilakukan adalah:

1. Bila (P-Value) $<0,05$ artinya variabel independen secara parsial mempengaruhi variabel dependen.

2. Bila (P-Value) $>0,05$ artinya variabel independen secara parsial tidak mempengaruhi variabel dependen

Menurut J. Supranto (2009 : 335), Apabila nilai t_hitung > tabel_tabel maka variabel independen secara individual mempengaruhi variabel dependen (Ha diterima dan Ho ditolak), sebaliknya jika thitung $<\mathrm{t}$ _tabel maka variabel independen tidak mempegaruhi variabel dependen $(\mathrm{Ha}$ ditolah dan Ho diterima

\section{b. Koefesien Determinasi}

Koefisien determinasi (R2) pada intinya mengukur seberapa jauh kemampuan variabel independen dalam menjelaskan variabel dependen. Besarnya variable independen dalam menjelaskan variabel dependen dapat diketahui melalui nilai koefisien determinasi. (Sugiyono, 2011: 257).
HASIL

Berikut ini hasil uji validitas untuk tiap-tiap variabel dengan menggunakan SPSS 23 sebagai berikut :

\section{Tabel Uji validitas variabel Kualitas Pelayanan}

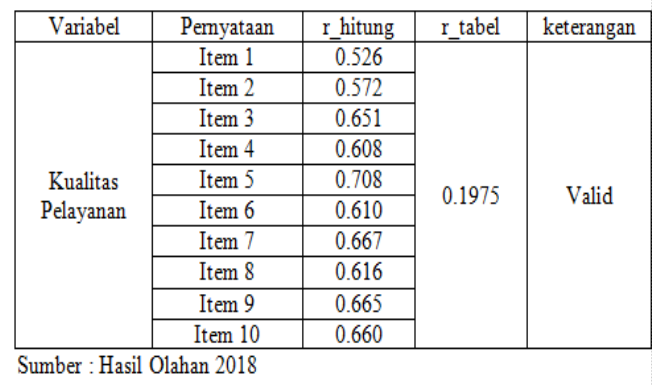

Tabel Uji Validitas Variabel Kepuasan

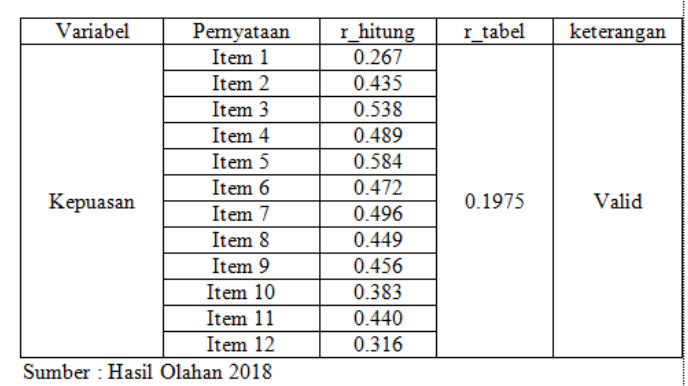

Berdasarkan tabel di atas, dapat dijelaskan bahwa semua item pernyataan kualitas pelayanan sudah valid yaitu nilai r_hitung > nilai r_tabel (0.1975).

Tabel Uji Reliabilitas Variabel

\begin{tabular}{|c|l|c|c|}
\hline $\mathrm{N}_{0}$ & \multicolumn{1}{|c|}{ Variabel } & Cronbach's Alpha & Keterangan \\
\hline 1 & KualitasPelayanan $(\mathrm{X})$ & 0.828 & Reliabel \\
\hline 2 & Kepuasan $(\mathrm{Y})$ & 0.635 & Reliabel \\
\hline
\end{tabular}

Berdasarkan tabel di atas diketahui nilai Cronbach's Alpha untuk seluruh variabel memiliki nilai lebih besar dari 0.60 maka dapat disimpulkan bahwa variabel bebas (X) dan variabel terikat (Y) sudah reliabel atau dapat dipercaya.

\section{Uji Normalitas}

Uji normalitas digunakan untuk mengetahui apakah sampel data berdistribusi normal atau tidak. Uji ini biasanya digunakan untuk mengukur data berskala ordinal, interval atau pun rasio. Berikut adalah hasil uji normalitas pada 
SPSS 23 sebagaimana dapat dilihat pada gambar 1 berikut ini:

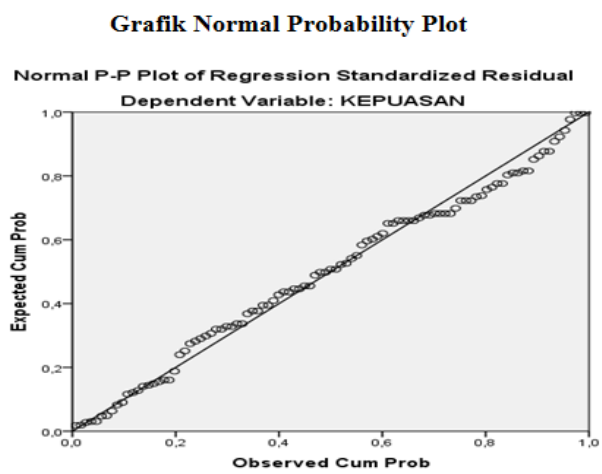

Dari gambar 1 di atas, dapat dilihatbahwa data menyebar sekitar garis diagonal dan mengikuti arah garis diagonal, maka model regresi memenuhi asumsi normalitas.

\section{Uji Regresi Liniear Sederhana}

Untuk mengetahui pengaruh Kualitas Pelayanan terhadap Kepuasan Nasabah di PT. BPRS Berkah Dana Fadhilillah Air Tiris Kampar digunakan analisis statistik dengan regresi linear sederhana. Untuk pengolahan data penelitian dilakukan dengan menggunakan program pengolahan data SPSS 23 (statistic package social science) dengan $a=0,05(5 \%)$ yang dapat dilihat pada tabel berikut:

Tabel Uji Regresi Liniear Sederhana

\begin{tabular}{|c|c|c|c|c|c|c|}
\hline \multicolumn{7}{|c|}{ Coefficients $^{\mathrm{a}}$} \\
\hline \multirow{2}{*}{\multicolumn{2}{|c|}{ Model }} & \multicolumn{2}{|c|}{$\begin{array}{c}\text { Unstandardized } \\
\text { Coefficients }\end{array}$} & \multirow{2}{*}{\begin{tabular}{|c|}
$\begin{array}{c}\text { Standardized } \\
\text { Coefficients }\end{array}$ \\
Beta \\
\end{tabular}} & \multirow[b]{2}{*}{$\mathrm{t}$} & \multirow[b]{2}{*}{ Sig. } \\
\hline & & $B$ & Std. Error & & & \\
\hline \multirow[t]{2}{*}{1} & (Constant) & 24,298 & 3,573 & & 6,800 &, 000 \\
\hline & PELAYANAN & ,541 & 083 & .552 & 6,518 &, 000 \\
\hline
\end{tabular}

Dari tabel di atas dapat diperoleh persamaan regresi linier sederhana sebagai berikut : $\mathrm{Y}=24.298+0.541 \mathrm{X}$

Persamaan ini dapat diartika sebagai berikut : 1. Konstanta sebesar 24.298, artinya jika variabel bebas bernilai nol, maka kepuasan nasabah PT. BPRS Berkah Dana Fadhililah Kampar bernilai 24.298.

2. Koefisien regresi variabel kualitas pelayanan (X) sebesar 0.541 , artinya jika

Eko dan Bisnis (Riau Economics and Business Reviewe) Volume 10, Nomor 4, 27 Desember 2019 variabel kualitas pelayanan (X) mengalami kenaikan satu satuan, maka kepuasan nasabah PT. BPRS Berkah Dana Fadhililah Kampar juga mengalami kenaikan sebesar 0.541 satuan, begitu juga sebalinyak jika terjadi penurunan.

Dari penjelasan di atas dapat disimpulkan bahwa, terjadinya hubungan positif antara kualitas pelayanan dan kepuasan hai ini terlihat dari koefisien regresi yang bernilai positif. Semakin baik pelayanan maka kepuasan nasabah PT. BPRS Berkah Dana Fadhililah Kampar juga akan baik.

\section{Uji Hipotesis}

\section{Uji Parsial (uji t)}

Uji_t adalah uji statistik yang digunakan untuk menguji hipotesis penelitian, yaitu apakah menerima hipotesis atau menolak. Yaitu dengan membandingkan antara nilai t_hitung dengan nilai t_tabel. Menentukan t_tabel dengan rumus : $\mathrm{n}-2$, baris dan alfa $0.05 / 2$, kolom, maka diperoleh : 99-2 = 97 (baris) dan alfa 0.05/2 (kolom), maka diperoleh t_tabel yaitu 1.98472. Berikut adalah hasil uji_t :

\section{Tabel Uji t}

\begin{tabular}{|l|r|r|r|r|r|}
\hline \multirow{4}{*}{ Model } & \multicolumn{2}{|c|}{$\begin{array}{c}\text { Unstandardized } \\
\text { Coefficients }\end{array}$} & $\begin{array}{c}\text { Standardized } \\
\text { Coefficients }\end{array}$ & & \\
\cline { 2 - 5 } & \multicolumn{1}{|c|}{ B } & Std. Error & Beta & \multicolumn{1}{c|}{ T } & Sig. \\
\hline (Constant) & 24,298 & 3,573 & & 6,800 &, 000 \\
PELAYANAN &, 541 &, 083 &, 552 & 6,518 &, 000 \\
\hline
\end{tabular}

Berdasarkan tabel 5.34 di atas, dapat disimpulkan bahwa nilai t_hitung adalah 6.518 dengan tingkat signifikan 0.00. Jadi t_hitung > t_tabel $(6.518>1.984)$ dan PValue $<0.05(0.00<0.05)$ maka Ho ditolak. Artinya bahwa variabel bebas (kualitas pelayanan) memiliki pengaruh yang signifikan terhadap variabel terikat (kepuasan nasabah) pada PT. BPRS Berkah dana Fadhililah Kampar.

\section{Uji Koefisien Determinasi $\left(\mathbf{R}^{2}\right)$}

Nilai koefisien determinasi atau $\mathrm{R}$ Square $\left(\mathrm{R}^{2}\right)$ digunakan untuk mengetahui 
seberapa besar persentase pengaruh variabel bebas (kualitas pelayanan ) terhadap variabel terikat ( kepuasan). Dari hasi pengolahan SPSS 23 diperoleh sebagai berikut :

Tabel Uji Koefisien Determinasi $\left(\mathbf{R}^{2}\right)$

\begin{tabular}{|c|c|c|c|c|}
\hline \multicolumn{5}{|c|}{ Model Summary } \\
\hline Model & $\mathrm{R}$ & $\begin{array}{c}\mathrm{R} \\
\text { Square }\end{array}$ & Adjusted R Square & $\begin{array}{l}\text { Std. Error of the } \\
\text { Estimate }\end{array}$ \\
\hline 1 &, $552^{\mathrm{a}}$ & 305 & 297 & 3,50003 \\
\hline
\end{tabular}

Berdasarkan tabel di atas, diperoleh angka R Square R2 sebesar 0.305 atau $30.5 \%$. Hal ini menunjukan bahwa persentase sumbangan pengaruh variabel bebas (kualitas pelayanan) terhadap variabel terikat (kepuasan) adalah sebesar 30.5\% sedangkan sisanya $69,5 \%$ dipengaruhi oleh faktor lain yang tidak termasuk dalam penelitian ini. Atau bahwa variabel terikat mampu dijelaskan oleh variabel bebas, artinya model yang digunakan sudah sesuai.

\section{SIMPULAN}

Berdasarkan hasil penelitian yang dilakukan mengenai pengaruh kualitas pelayanan terhadap kepuasan nasabah pada PT. BPRS Berkah Dana Fadhililah Kampar, maka berikut ini penulis dapat mengambil kesimpulan yaitu :

a. Dari analisis deskriptif diketahui rata-rata tanggapan responden terhadap pernyataan $\mathrm{X}$ (Kualitas Pelayanan) adalah sebesar 4.34 (sangat setuju) sedangkan rata-rata tanggapan responden terhadap pernyataan Y (Kepuasan) adalah sebesar 3.95 (setuju).

b. Dari hasil analisis kuantitatif diperoleh persamaan regresi linier sederhana yaitu $\mathrm{Y}=24.298+0.541 \mathrm{X}$, dari persamaan ini diketahui bahwa hubungan antara kualitas pelayanan dengan kepuasan adalah positif dimana koefisien kualitas pelayanan adalah 0.541. Dari pengujian hipotesis dengan uji $t$, didapatkan t_hitung $=6.518>\mathrm{t} \_$tabel $=1.984$ yang berarti kualitas pelayanan berpengaruh signifikan terhadap kepuasan nasabah BPRS Berkah Dana Fadhililah Kampar. Hal ini membuktikan hasil penelitian sama dengan hipotesis yang telah dibuat sebelumnya atau $\mathrm{Ha}$ diterimadan $\mathrm{Ho}$

Eko dan Bisnis (Riau Economics and Business Reviewe) Volume 10, Nomor 4, 27 Desember 2019 ditolak. Dari pengujian hipotesis juga didapat nilai koefisien determinasi (Rsquare) sebesar 0.305 , hal ini berarti bahwa besarnya pengaruh variabel kualitas pelayanan terhadap variabel kepuasan adalah sebesar $30.5 \%$ sedangkan sisanya $69.5 \%$ dipengaruhi oleh variabel lain

\section{DAFTAR RUJUKAN}

Chairiza, 2012, Pengaruh Bauran Pemasaran Terhadap Kepuasan Konsumen Pada Hotel Andalas di Bandar Lampung, (Tesis). Universitas Lampung, Bandar Lampung, $61 \mathrm{hlm}$.

Ghozali, Imam .2013. Aplikasi Analisis Multivariate dengan Program IBM SPSS 21 Update PLS Regresi. Semarang: Badan Penerbit Universitas Diponegoro.

Kotler dan Keller. 2009. Manajemen pemasaran, Edisi 13, Jilid 1, Alih Bahasa Bob Sabran, Jakarta: Erlanga Sugiyono. 2010. Metode Penelitian Pendidikan Pendekatan Kuantitatif, kualitatif, dan R\&D. Bandung: Alfabeta

Sugiyono .2011. Metode Penelitian Kuantitatif Kualitatif dan R \& D. Cetakan Ke 12. Bandung: Alfabeta.

Sugiyono. 2012. Metode Penelitian Kuantitatif Kualitatif dan R\&D. Bandung: Alfabeta.

Sunyoto, D. 2012. Manajemen Sumber Daya Manusia. Yogyakarta : CAPS

Rahmat, Yogie. 2018. Pengaruh Kualitas Pelayanan Terhadap Kepuasan Konsumen PT. Hero Supermarket TBK. Cabang Giant Ekstra Metropolitan City Panam Pekanbaru. Jurnal: Eko dan Bisnis (Riau Economic and Business Reviewe) Volume 9, Nomor 4, Desember 2018.

Tjiptono, Fandy dan Gregorius Chandra. 2011. Service, Quality and Satisfaction (ed 3). Yogyakarta, Andi.

Tjiptono, Fandy dan Gregorius Chandra 2012. Pemasaran Strategik.

Yogyakarta. Andi

P.ISSN: 1410-7988 E.ISSN: 2614-123X 
Tjiptono, Fandy. 2014. Pemasaran Jasa.

Andi : Yogyakarta

Zeithaml, Valerie, A and Bitner, Mary. 2010.

Pemasaran jasa: Integrasi Fokus

Pelanggan di Perusahaan, Alih Bahasa:

Ratih Hurriyati, Alfabeta. Bandung

Zulian Yamit. 2013. Manajemen Kualitas

Produk dan Jasa, Yogyakarta: Ekonisia. 